\title{
COMPARISON OF ADVANCED OAT BREEDING LINES IN LITHUANIA
}

\author{
Vida Danytè \\ Institute of Agriculture Lithuanian Research Centre for Agriculture and Forestry, \\ Instituto av. 1, 58344 Akademija, Kèdainiai distr. LITHUANIA; \\ vida@।zi.It
}

Communicated by Zinta Gaile

\begin{abstract}
Advanced oat breeding lines were investigated in 2009-2011 at the Institute of Agriculture of Lithuanian Research Centre for Agriculture and Forestry. The highest grain yield $\left(4.10 \mathrm{tha} \mathrm{h}^{-1}\right)$ and fat content (4.41\%) was in 2009 and the highest protein and starch content (12.54\% and 51.4\%) was in 2011. Every year the yield of oat line LIA 1526-9 was higher or similar to the standard variety yield. The breeding line LIA 1526-9 also gave good results for fat, protein and starch yield. Every year fat, protein and starch content of naked line 1579-1 was higher in comparison with standard variety Mina DS: respectively, $7.39 \%, 12.6 \%$, and $61.7 \%$ (standard variety $6.49 \%$, $12.3 \%$, and $55.7 \%$ ) in $2009,6.27 \%, 15.1 \%$, and $60.7 \%$ (standard variety $5.06 \%, 11.5 \%$, and $52.8 \%$ ) in 2010 and $6.24 \%, 15.1 \%$, and $63.6 \%$ (standard variety $5.66 \%, 14.0 \%$, and $58.4 \%$ ) in 2011. Significantly higher yields of fat, protein and starch per hectare were obtained in 2009 and reached 176, 454, and $1910 \mathrm{~kg} \mathrm{ha}^{-1}$. Fat, protein and starch yields per ha of naked oat breeding lines were not higher than those of hulled oat breeding lines because of their low grain yield.
\end{abstract}

Key words: Avena sativa, yield, fat, protein.

\section{INTRODUCTION}

Oats (Avena sativa L.) is an important crop worldwide (Butt et al., 2008; Rivera-Reyes et al., 2008). Despite declining production areas, oat still attracts attention because of its high nutritive value as animal feed and human food (Tiwari and Cummins, 2009; Zhao et al., 2009). The area of oats grown in Lithuania is on average 60000 ha (Kulikauskas and Statkevičiūtè 2008).

Different varieties of cereals respond differently to agro climatic conditions of a particular area due to differences in their genetic make up and physical life processes. Selection of improved and high yield genotypes having a wide range of adaptation to agro climatic conditions is essential to increase grain yield (Shah et al., 2002). Oat breeding in Lithuania was started in 1922. During the first ten-year period, the chief breeding method was individual selection. Later the initial material in most cases was developed by intervarietal hybridization. Oat varieties Stipruolès, Dotnuvos baltosios, Gyrūnès, Skaistūnès, Sdabrès, Šušvè, Jaugila, Migla DS and hulles Mina DS were developed within the period of the last 90 years (Kulikauskas and Sprainaitiene, 1998).

Oats can be broadly classified as hulled and naked. The naked oats are nutritionally superior compared to conventional hulled oats. Naked oats have a thin non-lignified husk on the outside of the grain, which falls off during harvesting, resulting in a grain of energy, protein and lipid and lower fibre content compared with hulled oats (Givens and Brunnen, 1987; Bhatty, 1995; Tiwari and Cummins, 2009).

The amount of oats used for human consumption has increased because of the dietary benefits (Tiwari and Cummins, 2009).

Oat groats have the highest lipid concentration among cereal grains. Thus, the lipids and lipid-associated components in the groat are important to the functionality of oat products. The high lipid content of oats provides a benefit in animal feed, as it has high energy value and good fatty acid composition (Zhou et al., 1998).

Amino acid analysis and comparative feeding studies show that oat is equal or superior in nutritional quality to other commonly used cereal grains. Reports by various workers indicated that varietal and environmental conditions influence the amino acid composition of oat protein (Hischke et al. 1968).

The aim of this investigation was to evaluate the agronomic traits and chemical composition of advanced Lithuanian spring oat (Avena sativa $\mathrm{L}$.) breeding lines, which later can be used for development of new hulled and hull-less oat varieties with better nutrition value. 


\section{MATERIALS AND METHODS}

Advanced oat lines of hulled and naked oats (Avena sativa L.) were investigated in 2009-2011 at the Institute of Agriculture of Lithuanian Research Centre for Agriculture and Forestry (Table 1). The experiment was carried out as crop rotation by the Cereal Breeding Department. The previous crop was pea. Oat was sown at a rate of 5 million seed ha ${ }^{-1}$ with $12-\mathrm{cm}$ row spacing, in $15 \mathrm{~m}^{2}$ plots in four replicates. The soil type was light loamy Gleyic Cambisoil with content of available phosphorus $\left(\mathrm{P}_{2} \mathrm{O}_{5}\right) 200 \mathrm{mg} \mathrm{kg}^{-1}$ in 2009 , $156 \mathrm{mg} \mathrm{kg}^{-1}$ in 2010 and $163 \mathrm{mg} \mathrm{kg}^{-1}$ in 2011, available potassium $\left(\mathrm{K}_{2} \mathrm{O}\right) 188,168,190 \mathrm{mg} \mathrm{kg}^{-1}$, respectively, $\mathrm{pH}_{\mathrm{KCl}}$ $6,5,6,0$ and 5,1 respectively.

Oat breeding lines were selected according to many characteristics, such as yield, lodging, resistance to fungal diseases (loose smut, leaf blotch, crown rust), chemical composition. New breeding lines with good traits were added every year and some breeding lines, which had not shown good traits, were removed. The variety Ivory was grown as a standard variety in 2009 and 2010 and Lithuanian variety Migla DS and German varieties Carron and Typhon were grown in 2011. Lituanian variety Mina DS was grown as a standard naked oat variety.

Climatic diagrams (Figs. 1, 2, 3, 4) show the course of rainfall and temperature in 2009-2011. Periods of drought occured when red line showing temperature rose above the blue line (precipitation) in the diagrams. Spring of 2009 was dry, but there was enough moisture for normal oat germination. Precipitation in June was extremely high. 2010 was without drought periods. Precipitation in July was high and harvesting conditions were complicated. Two drought periods occurred in 2011, but they did not strongly influence oat growth and development.

The data were processed by means of ANOVA statistical analysis using the Statgrafics Plus software package.

\section{RESULTS}

Spring oat yield, plant height and some quality characteristics had normal or very close to normal distributions (Table 2 ). Therefore, average values were used with standard deviation as a measure of data dispersion.

Weather conditions had significant influence on oat grain yield and chemical composition of grain (Table 3). The highest grain yield and fat content in grain was in 2009 and

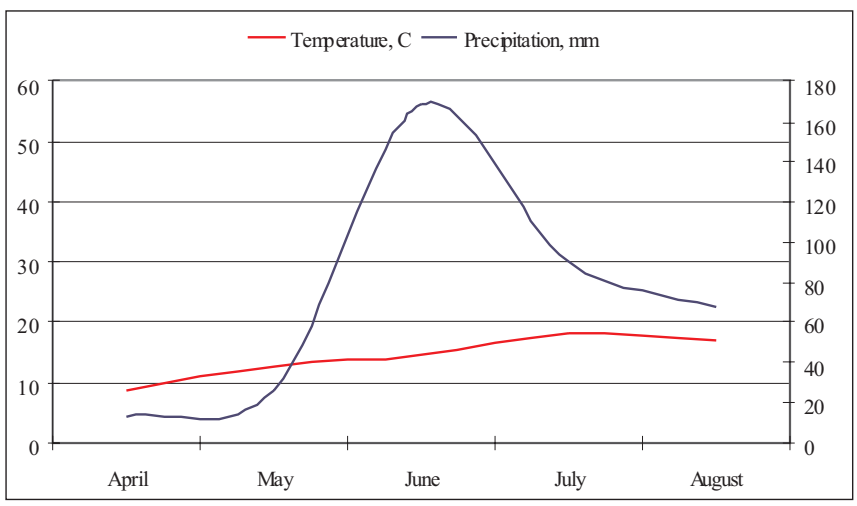

Fig. 1. Climatic diagram, 2009, Lithuania (temperature - upper curve).

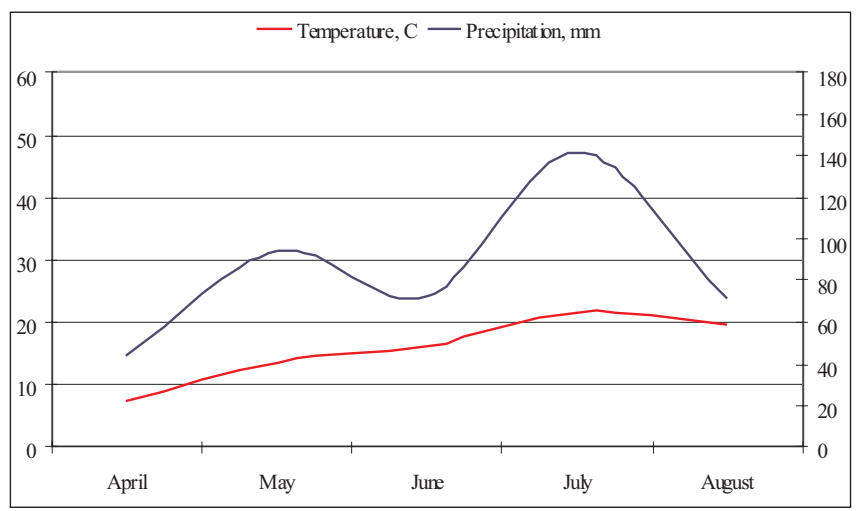

Fig. 2. Climatic diagram, 2010, Lithuania (temperature - upper curve).

INVESTIGATED BREEDING LINES

\begin{tabular}{llll}
\hline \multicolumn{1}{c|}{ Breeding line } & \multicolumn{1}{c}{ Cross combination } & \multicolumn{1}{c}{ Breeding line } & Cross combination \\
\hline LIA 1396-44 & WW17579 / 1152-192 & LIA 1614-26 & Mell / Vietinės (Baškirija) \\
LIA 1416-2 & Goral / 1313-100 & LIA 1619-22 & Obyknovennyj / 1396-44 \\
LIA 1518-7 & $1313-100 /$ Michal & LIA 1621-4 & Belinda / Abel \\
LIA 1526-9 & Viet Ispanija / 1373-14 & LIA 1629-3* & Mestny / Abel \\
LIA 1532-6 & 1373-14 / Edit & LIA 1631-9* & VIR 1998 / Abel \\
LIA 1566-12* & Bueler /Abel & LIA 1632-3 & Cwal /1491-11 \\
LIA 1562-20 & AC 805 / Rhianon & LIA 1638-9 & Flamingstern / Flamingsprofi \\
LIA 1578-20 & Forward / Abel & LIA 1639-8 & Flamingstern / Flamingsprofi \\
LIA 1579-1* & Bordeweis / Abel & LIA 1639-11 & Flamingstern / Flamingsprofi \\
LIA 1606-26 & Flamingstern / Veles & LIA 1639-37 & Triton / LPSH 00503 \\
LIA 1609-3 & Freddy / Neson & LIA 1644-47 & Triton / LPSH 00503 \\
LIA 1611-55 & Cwal / Markus & LIA 1644-68 & Hja 73006 / Omihi \\
LIA 1614-15 & Condor / Perona & LIA 1645-26 &
\end{tabular}

* naked oat breeding lines 


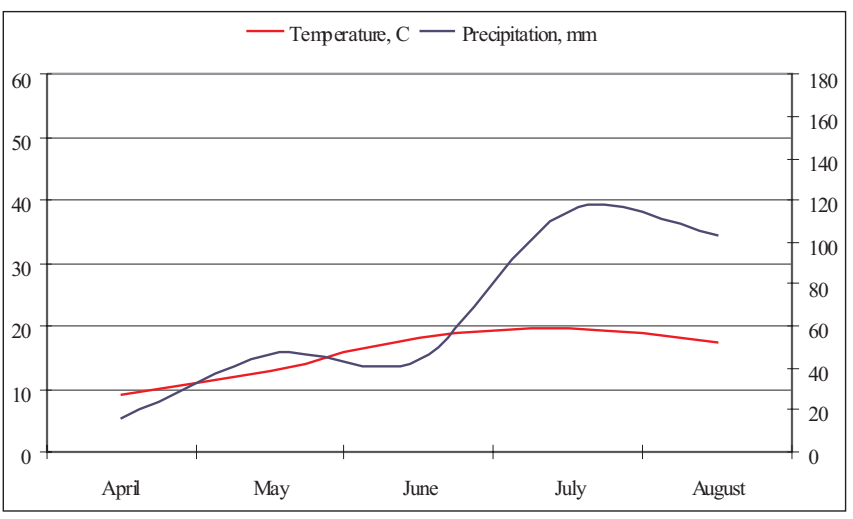

Fig. 3. Climatic diagram, 2011, Lithuania (temperature - upper curve).

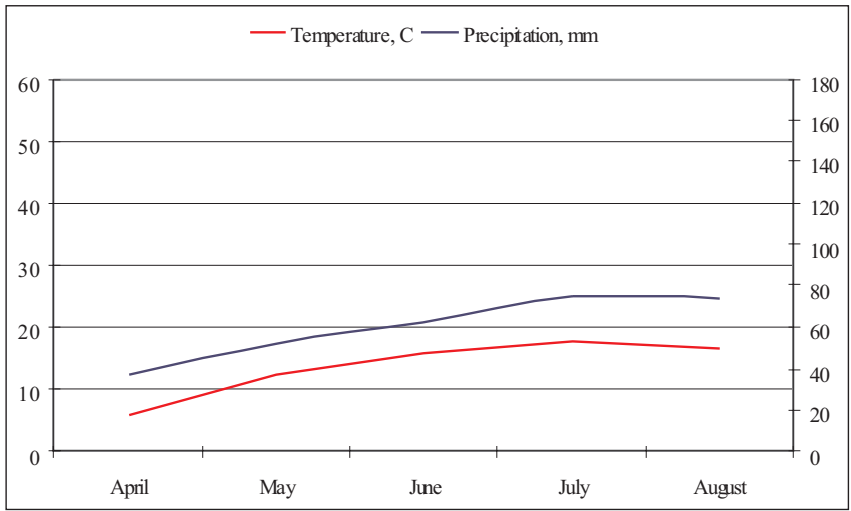

Fig. 4. Climatic diagram, 1924-2010, Lithuania (temperature - upper curve).

Table 2

STATISTICAL CHARACTERISTICS OF OAT BREEDING LINES, 2009-2011

\begin{tabular}{l|cc|c|c|c}
\hline \multicolumn{1}{c|}{ Statistic } & $\begin{array}{c}\text { Yield, } \\
\mathrm{t} \mathrm{ha}^{-1}\end{array}$ & $\begin{array}{c}\text { Plant } \\
\text { height, cm }\end{array}$ & Fat \% & Protein \% & Starch \% \\
\hline Average & 3.38 & 95.5 & 4.21 & 12.01 & 50.10 \\
Variance & 1.14 & 28.9 & 1.48 & 2.48 & 44.12 \\
Stand. deviation & 1.07 & 11.35 & 1.22 & 1.57 & 6.64 \\
Minimum & 1.4 & 75.0 & 2.37 & 9.80 & 38.7 \\
Maximum & 5.4 & 131.0 & 7.39 & 16.20 & 63.6 \\
Stand. skewness & 0.32 & 3.16 & 2.21 & 1.88 & 1.72
\end{tabular}

Table 3

DYNAMICS OF OAT LINES CHARACTERISTICS. 2009-2011

\begin{tabular}{c|c|c|c|c|c}
\hline Year & $\begin{array}{c}\text { Yield, } \\
\mathrm{t} \mathrm{ha}^{-1}\end{array}$ & $\begin{array}{c}\text { Plant } \\
\text { height, } \mathrm{cm}\end{array}$ & Fat \% & Protein \% & Starch \% \\
\hline 2009 & $4.10 \mathrm{a}$ & $95.8 \mathrm{~b}$ & $4.41 \mathrm{a}$ & $11.12 \mathrm{~b}$ & $47.5 \mathrm{~b}$ \\
2010 & $3.19 \mathrm{~b}$ & $112.0 \mathrm{a}$ & $3.91 \mathrm{ab}$ & $12.07 \mathrm{a}$ & $47.6 \mathrm{~b}$ \\
2011 & $2.95 \mathrm{c}$ & $92.4 \mathrm{c}$ & $3.89 \mathrm{~b}$ & $12.54 \mathrm{a}$ & $51.4 \mathrm{a}$
\end{tabular}

Means with the same letter in the column do not differ significantly $(P<0.05)$

the highest protein and starch content was in 2011. Plant height significantly differed between years.

The yield of oat lines LIA 1609-3 and LIA 1611-55 was significantly higher compared with that of the standard variety in 2009 (Table 4). Thirteen lines including naked oat
Table 4

BREEDING LINES CHARACTERISTICS, 2009

\begin{tabular}{l|cc|c|c|c}
\hline Breeding line & $\begin{array}{c}\text { Yield, t } \\
\text { ha }^{-1}\end{array}$ & $\begin{array}{c}\text { Plant height, } \\
\mathrm{cm}\end{array}$ & Fat, \% & Protein, \% & Starch, \% \\
\hline LIA 1578-20 & $3.15 \mathrm{a}$ & $100.0 \mathrm{bcdefg}$ & 4.81 & 12.7 & 51.2 \\
LIA 1396-44 & $4.06 \mathrm{~b}$ & $89.2 \mathrm{ab}$ & 3.23 & 10.0 & 47.6 \\
LIA 1614-15 & $4.10 \mathrm{bc}$ & $103.3 \mathrm{cdefg}$ & 4.33 & 11.8 & 43.7 \\
LIA 1614-26 & $4.23 \mathrm{bc}$ & $91.7 \mathrm{abc}$ & 4.14 & 10.9 & 43.1 \\
LIA 1532-6 & $4.25 \mathrm{bc}$ & $93.3 \mathrm{abcd}$ & 3.47 & 10.1 & 48.7 \\
LIA 1518-7 & $4.27 \mathrm{bc}$ & $106.7 \mathrm{efg}$ & 3.74 & 11.1 & 44.6 \\
LIA 1416-2 & $4.48 \mathrm{bcd}$ & $108.3 \mathrm{efg}$ & 4.28 & 9.8 & 38.7 \\
LIA 1526-9 & $4.48 \mathrm{bcd}$ & $93.3 \mathrm{abcd}$ & 3.72 & 10.1 & 45.7 \\
LIA 1562-20 & $4.62 \mathrm{bcde}$ & $81.7 \mathrm{a}$ & 3.15 & 9.8 & 41.5 \\
St. variety & $4.67 \mathrm{~cd}$ & $91.7 \mathrm{ab}$ & 3.28 & 11.1 & 47.5 \\
LIA 1606-26 & $5.18 \mathrm{de}$ & $96.7 \mathrm{bcde}$ & 4.35 & 10.6 & 43.0 \\
LIA 1609-3 & $5.35 \mathrm{e}$ & $98.3 \mathrm{bcdef}$ & 4.15 & 10.1 & 44.8 \\
LIA 1611-55 & $5.35 \mathrm{e}$ & $100.0 \mathrm{bcdefg}$ & 4.93 & 11.1 & 45.0 \\
& & Naked oat & & \\
LIA 1566-12 & $2.55 \mathrm{a}$ & $111.7 \mathrm{fg}$ & 6.36 & 14.0 & 56.0 \\
Stand. variety & $2.55 \mathrm{a}$ & $100.0 \mathrm{bcdefg}$ & 6.49 & 12.3 & 55.7 \\
LIA 1579-1 & $2.75 \mathrm{a}$ & $106.7 \mathrm{defg}$ & 7.39 & 12.6 & 61.7 \\
\hline
\end{tabular}

Means with the same letter in the column do not differ significantly $(\mathrm{P}<0.05)$

had higher fat content, and eight lines had protein and nine had higher starch content compared with those of the standard variety. Breeding lines LIA 1578-20 and LIA 1518-7 had higher fat, protein and starch content compared with those of the standard variety, but the yield of line LIA 1518-7 was lower and of line LIA 1578-20 was significantly lower. LIA $1562-9$ had the shortest straw, but for other parameters it had poorer results than did the standard variety. The naked oat line LIA 1579-1 yield was higher and it had higher fat, protein and starch content compared with those of the standard naked oat variety Mina DS.

The yield of oat line LIA 1526-9 was significantly higher compared with the average standard variety yield in 2010 (Table 5). The standard variety had the highest fat, protein

Table 5

BREEDING LINES CHARACTERISTICS, 2010

\begin{tabular}{l|cc|c|c|c}
\hline \multicolumn{1}{c|}{ Breeding line } & $\begin{array}{c}\text { Yield, } \\
\mathrm{t} \mathrm{ha}^{-1}\end{array}$ & $\begin{array}{c}\text { Plant } \\
\text { height }\end{array}$ & Fat, \% & Protein, \% & Starch, \% \\
\hline LIA 1632-3 & $3.08 \mathrm{c}$ & $109.0 \mathrm{ab}$ & 3.81 & 11.1 & 40.9 \\
LIA 1562-20 & $3.15 \mathrm{c}$ & $97.0 \mathrm{a}$ & 2.37 & 10.5 & 41.2 \\
LIA 1532-6 & $3.43 \mathrm{~cd}$ & $110.0 \mathrm{~b}$ & 3.17 & 9.9 & 45.9 \\
LIA 1619-22 & $3.58 \mathrm{~cd}$ & $109.0 \mathrm{ab}$ & 3.05 & 10.9 & 43.8 \\
St. variety & $3.62 \mathrm{~d}$ & $108.4 \mathrm{~b}$ & 5.12 & 11.8 & 52.0 \\
LIA 1526-9 & $4.32 \mathrm{e}$ & $110.0 \mathrm{~b}$ & 3.15 & 11.6 & 47.1 \\
& & Naked oat & & & \\
LIA 1566-12 & $1.43 \mathrm{a}$ & $131.0 \mathrm{~d}$ & 5.76 & 14.9 & 61.6 \\
LIA 1579-1 & $1.50 \mathrm{a}$ & $125.0 \mathrm{~cd}$ & 6.27 & 15.1 & 60.7 \\
LIA 1629-3 & $1.75 \mathrm{ab}$ & $105.0 \mathrm{ab}$ & 6.06 & 14.6 & 57.9 \\
LIA 1631-9 & $2.12 \mathrm{~b}$ & $107.0 \mathrm{ab}$ & 5.02 & 16.2 & 52.6 \\
Stand. variety & $2.22 \mathrm{~b}$ & $115.0 \mathrm{bc}$ & 5.06 & 11.5 & 52.8 \\
\hline
\end{tabular}

Means with the same letter in the column do not differ significantly $(P<0.05)$ 
and starch content. The yield of all naked oat lines were lower compared with the standard variety Mina DS, but fat, protein and starch content almost in all cases was the lower than for the standard variety.

Yield of nine varieties was higher compared with the average yield of standard varieties, but only the yield of line LIA 1532-6 was significantly higher in 2011 (Table 6). Naked oat variety LIA 1579-1 had the highest fat, protein and starch content and non-significantly higher grain yield, compared with naked oat standard variety Mina DS.

Table 6

BREEDING LINES CHARACTERISTICS, 2011

\begin{tabular}{l|c|c|c|c|c}
\hline $\begin{array}{c}\text { Breeding } \\
\text { line }\end{array}$ & $\begin{array}{c}\text { Yield, } \\
\mathrm{t} \mathrm{ha}^{-1}\end{array}$ & $\begin{array}{c}\text { Plant } \\
\text { height, cm }\end{array}$ & Fat, \% & Protein, \% & Starch, \% \\
\hline LIA 1619-22 & $2.63 \mathrm{~cd}$ & $92.5 \mathrm{~cd}$ & 3.29 & 12.4 & 48.2 \\
LIA 1632-3 & $2.79 \mathrm{de}$ & $90.0 \mathrm{abcd}$ & 3.89 & 11.4 & 46.9 \\
LIA 1638-9 & $2.90 \mathrm{def}$ & $85.0 \mathrm{abc}$ & 3.80 & 11.9 & 49.5 \\
LIA 1621-4 & $2.90 \mathrm{def}$ & $83.8 \mathrm{ab}$ & 3.98 & 12.6 & 47.4 \\
St. varieties & $3.02 \mathrm{def}$ & $88.3 \mathrm{abc}$ & 3.21 & 12.4 & 50.5 \\
LIA 1639-8 & $3.06 \mathrm{defg}$ & $85.0 \mathrm{abc}$ & 3.09 & 11.5 & 49.6 \\
LIA 1644-68 & $3.10 \mathrm{defg}$ & $82.5 \mathrm{a}$ & 3.18 & 11.7 & 52.4 \\
LIA 1645-26 & $3.10 \mathrm{defg}$ & $103.8 \mathrm{f}$ & 3.55 & 13.0 & 46.4 \\
LIA 1562-20 & $3.12 \mathrm{defg}$ & $82.5 \mathrm{a}$ & 2.89 & 12.2 & 48.1 \\
LIA 1526-9 & $3.20 \mathrm{defg}$ & $91.25 \mathrm{bcd}$ & 3.43 & 11.7 & 52.4 \\
LIA 1639-37 & $3.28 \mathrm{efg}$ & $86.2 \mathrm{abc}$ & 3.04 & 11.3 & 62.3 \\
LIA 1644-47 & $3.42 \mathrm{fg}$ & $82.5 \mathrm{a}$ & 3.75 & 12.8 & 49.2 \\
LIA 1639-11 & $3.48 \mathrm{fg}$ & $87.5 \mathrm{abcd}$ & 3.55 & 12.6 & 51.3 \\
LIA 1532-6 & $3.64 \mathrm{~g}$ & $91.2 \mathrm{bcd}$ & 2.83 & 11.8 & 47.9 \\
& & Naked oat & & 63.6 \\
LIA 1566-12 & $1.44 \mathrm{a}$ & $101.2 \mathrm{ef}$ & 5.88 & 13.1 & 62.3 \\
LIA 1631-9 & $1.64 \mathrm{ab}$ & $90.0 \mathrm{abcd}$ & 5.82 & 14.4 & 61.1 \\
St. variety & $2.14 \mathrm{bc}$ & $94.4 \mathrm{de}$ & 5.66 & 14.0 & 58.4 \\
LIA 1579-1 & $2.17 \mathrm{bc}$ & $103.8 \mathrm{f}$ & 6.24 & 15.1 & 63.6 \\
LIA 1629-3 & $2.61 \mathrm{~cd}$ & $91.2 \mathrm{bcd}$ & 5.84 & 13.7 & 60.5 \\
\hline
\end{tabular}

Means with the same letter in the column do not differ significantly $(\mathrm{P}<0.05)$

Significantly higher yields of fat, protein and starch per hectare were obtained in 2009 (Table 7).

Breeding lines LIA 1606-26, LIA 1609-3 and LIA 1611-55 gave the highest yield of fat, protein and starch per ha in 2009 (Table 8). The reason was high yield and high fat content of these lines.

All investigated oat breeding lines had lower yield of fat $\mathrm{kg}$ per ha compared with the standard variety in 2010, which

Table 7

DYNAMICS OF FAT, PROTEIN AND STARCH AMOUNT PER HA, 2009-2011

\begin{tabular}{ccccc}
\hline \multicolumn{1}{c}{ Year } & Fat, $\mathrm{kg} \mathrm{ha}^{-1}$ & Protein, $\mathrm{kg} \mathrm{ha}^{-1}$ & ${\text { Starch, } \mathrm{kg} \mathrm{ha}^{-1}}$ \\
\hline 2009 & $176 \mathrm{a}$ & $451 \mathrm{a}$ & $1910 \mathrm{a}$ \\
2010 & $112 \mathrm{~b}$ & $329 \mathrm{~b}$ & $1337 \mathrm{~b}$ \\
2011 & $108 \mathrm{~b}$ & $352 \mathrm{~b}$ & $1476 \mathrm{~b}$
\end{tabular}

Means with the same letter in the column do not differ significantly $(\mathrm{P}<0.05)$
Table 8

FAT, PROTEIN AND STARCH YIELD, 2009-2011

\begin{tabular}{|c|c|c|c|c|c|c|c|c|c|}
\hline \multirow{2}{*}{$\begin{array}{l}\text { Breeding } \\
\text { line }\end{array}$} & \multicolumn{3}{|c|}{ Fat, $\mathrm{kg} \mathrm{ha}^{-1}$} & \multicolumn{3}{|c|}{ Protein, $\mathrm{kg} \mathrm{ha}^{-1}$} & \multicolumn{3}{|c|}{ Starch, $\mathrm{kg} \mathrm{ha}^{-1}$} \\
\hline & 2009 & 2010 & 2011 & 2009 & 2010 & 2011 & 2009 & 2010 & 2011 \\
\hline LIA $1578-20$ & 152 & - & - & 400 & - & - & 1613 & - & - \\
\hline LIA 1396-44 & 131 & - & - & 406 & - & - & 1935 & - & - \\
\hline LIA 1614-15 & 178 & - & - & 484 & - & - & 1792 & - & - \\
\hline LIA $1614-26$ & 175 & - & - & 461 & - & - & 1823 & - & - \\
\hline LIA $1532-6$ & 148 & 109 & 103 & 429 & 338 & 429 & 2070 & 1574 & 1744 \\
\hline LIA $1518-7$ & 160 & - & - & 475 & - & - & 1904 & - & - \\
\hline LIA $1416-2$ & 192 & - & - & 439 & - & - & 1734 & - & - \\
\hline LIA $1526-9$ & 167 & 136 & 110 & 452 & 501 & 374 & 2047 & 2035 & 1677 \\
\hline LIA $1562-20$ & 146 & 75 & 90 & 453 & 331 & 381 & 1917 & 1298 & 1501 \\
\hline $\begin{array}{l}\text { Stand. } \\
\text { varieties }\end{array}$ & 153 & 185 & 97 & 518 & 427 & 374 & 2218 & 1882 & 1525 \\
\hline LIA $1606-26$ & 225 & - & - & 549 & - & - & 2227 & - & - \\
\hline LIA 1609-3 & 222 & - & - & 540 & - & - & 2397 & - & - \\
\hline LIA 1611-55 & 264 & - & - & 594 & - & - & 2407 & - & - \\
\hline LIA $1632-3$ & - & 117 & 108 & - & 342 & 318 & - & 1260 & 1308 \\
\hline LIA $1619-22$ & - & 109 & 86 & - & 390 & 326 & - & 1568 & 1268 \\
\hline LIA $1638-9$ & - & - & 110 & - & - & 345 & - & - & 1435 \\
\hline LIA 1621-4 & - & - & 115 & - & - & 365 & - & - & 1383 \\
\hline LIA $1639-8$ & - & - & 94 & - & - & 352 & - & - & 1518 \\
\hline LIA $1644-68$ & - & - & 99 & - & - & 363 & - & - & 1624 \\
\hline LIA $1645-26$ & - & - & 110 & - & - & 403 & - & - & 1438 \\
\hline LIA $1639-37$ & - & - & 100 & - & - & 371 & - & - & 2043 \\
\hline LIA $1644-47$ & - & - & 128 & - & - & 438 & - & - & 1682 \\
\hline LIA 1639-11 & - & - & 123 & - & - & 438 & - & - & 1785 \\
\hline \multicolumn{10}{|c|}{ Naked oat } \\
\hline LIA $1566-12$ & 162 & 82 & 85 & 357 & 213 & 188 & 1428 & 881 & 897 \\
\hline Stand. variety & 166 & 112 & 121 & 314 & 255 & 300 & 1420 & 1172 & 1250 \\
\hline LIA 1579-1 & 203 & 94 & 135 & 346 & 226 & 328 & 1697 & 910 & 1380 \\
\hline LIA $1629-3$ & - & 106 & 152 & - & 255 & 358 & - & 1013 & 1579 \\
\hline LIA $1631-9$ & - & 106 & 95 & - & 343 & 236 & - & 1115 & 1002 \\
\hline Average & 176 & 112 & 108 & 454 & 329 & 352 & 1910 & 1337 & 1461 \\
\hline
\end{tabular}

was due to the unusually high fat content in the standard variety. Only breeding line LIA 1526-9 had higher protein yield.

Fat, protein and starch yield of breeding lines LIA 1644-47, LIA 1639-11 and LIA 1532-6 was the highest in 2011.

\section{DISCUSSION}

Various factors are considered responsible for better crop harvest, among which high potential varieties offer a tremendous scope (Shah et al., 2002). The yield of oat breeding lines in our investigation fluctuated from 1.4 to $5.4 \mathrm{t}$ $\mathrm{ha}^{-1}$. The average yield of breeding lines significantly differed every year. The highest was obtained in 2009, it decreased next year and in 2011 it was the lowest and did not reach $3 \mathrm{t} \mathrm{ha}^{-1}$. The difference in grain yield could have been influenced by different amount of precipitation, especially in June. 
Plant breeders should pay attention to biochemical indicators of cereals when developing new oat varieties for food production (Zute et al., 2011; Berga and Zute 2012). Surveys have reported a wide range $(2-12 \%)$ of fat content in oats (Sahasrabudhe, 1979). Some oat lines can contain up to $18 \%$ fat (Banas et al., 2007). It has also been shown that fat content is under genetic control, suggesting that the fat content can be increased (Sahasrabudhe, 1979). In our investigation the average fat content in grain was 4.21. Fat percent in grain had the same trend as grain yield — it was highest in 2009, lower in 2010 and the lowest in 2011, with a range from 2.37 to $7.39 \%$. The lowest fat percent occurred for breeding line LIA $1562-20$ in 2010. In 2009, it was also the lowest compared with that of other lines. In 2011, only one line had lower fat content than line LIA 1562-20. The highest fat content every year was obtained for naked oat breeding line LIA $1579-1$. The highest fat yield $\left(176 \mathrm{~kg} \mathrm{ha}^{-1}\right.$ in 2009) was due to high grain yield and fat content that year.

The use of oats as human and animal food has been justified by their taste and high nutritive value, when compared to other cereal grains, and a high protein content and protein value (Pedó et al., 1999). Oats have good quality protein and high protein content compared with other cereal grain (Wu, 1983). Oat protein content is about 13-17\% (Butt et al., 2008; Adams, 2009). In our investigation protein content of oat breeding lines was lower than these values, ranging from 9.80 to 16.20 with an average of $12.01 \%$. The lowest content occurred for breeding lines LIA 1562-20 and LIA 1416-2 in 2009. Protein content of breeding line LIA 1562-20 was not high also in 2010 and 2011 and this line can be described as having low fat and protein content. The average protein yield was from $329 \mathrm{~kg} \mathrm{ha}^{-1}$ in 2010 to 454 $\mathrm{kg} \mathrm{ha}^{-1}$ in 2009.

In conclusion, the yield of oat breeding line LIA 1526-9 every year was higher or similar to that of the standard variety yield. The breeding line LIA 1526-9 also gave good results for fat, protein and starch yield. Fat, protein and starch yield per ha of naked oat breeding lines was not higher compared with hulled oat breeding lines because of their low grain yield. Fat, protein and starch content of naked oat breeding line LIA 1579-1 every year was higher compared with that of standard variety Mina DS. Plants of naked oat breeding lines LIA 1579-1 and LIA 1566-12 every year were the highest.

\section{REFERENCES}

Adams, C. (2011). A new healthier oat.

http://pdfcast.org/pdf/a-new-healthier-oat.

Banas, A., Dębski, H., Banas, W., Heneen, W. K., Dahlqvist, A., Bafor, M., Gummeson, P., Marttila, S., Ekman, A., Carlsson, A. S., Stymne, S. (2007). Lipids in grain tissues of oat (Avena sativa): Differences in content, time of deposition, and fatty acid composition. J. Exp. Bot., 58, 2463-2470.

Berga, L., Zute, S. (2012). Variability in $\alpha$-tocotherol concentration of husked and naked oat genotypes. Proc. Latvian. Acad. Sci., Section B, 66 (1/2), 26-29.

Bhatty, R. S. (1995). Laboratory and pilot plant extraction and purification of $\beta$-glucans from hull-less barley and oat brans. J. Cereal Sci., 22, 163-170.

Butt, M. S., Sadiq, M., Tahir-Nadeem, M., Khan, M. K. I., Shabir, R., Butt, M. S. (2008). Oat: Unique among the cereals. Eur. J. Nutr., 47, 68-79.

Givens, D. I., Brunnen, J. M. (1987). Nutritive value of naked oats for ruminants. Anim. Feed Sci. Technol., 18, 83-87.

Hischke, Jr. H. H., Potter, G. C., Graham, W. R. (1968). Nutritive value of oat protein. I. Varietal differences as measured by amino acid analysis and rat growth responses. Cereal Chem., 45, 374-378.

Kulikauskas, A., Statkevičiūtè, G. (2008). Oat naked-grain trait segregation in F2 plants and their selection for promising breeding lines. ZemdirbysteAgriculture, 95, 109-115.

Kulikauskas, A., Sprainaitienè, J. (1998). Avižų selekcija [Oat breeding]. In: Augalu selekcija [Plant Breeding] (pp. 59-63). Liekis, A. (ed.). Vilnius: Lietuvos mokslas (in Lithuanian).

Rivera-Reyes, J. G., Cortez-Bheza, E., Peraza-Luna, F. A., Serratos-Arévalo, J. C., Posos-Ponce P., Guevara-González, R. G., Torres-Pcheco, I., Guzmán-Maldonado, S. H. (2008). Agronomic traits associated to yield and quality in oat seeds. Asian J. Plant Sci., 7, 767-770.

Pedó, I., Sgarbieri, V. C., Gutkoski, L. C. (1999). Protein evaluation of four oat (Avena sativa L.) cultivars adapted for cultivation in south of Brazil. Pl. Food Hum., 53, 297-304.

Sahasrabudhe, M. R. (1979). Lipid composition of oats (Avena sativa L.). J. Amer. Oil Chem. Soc., 56, 80-84.

Shah, W. A., Bakht, J., Shafi, M., Khan, M. A. (2002). Yield and yield components of different cultivars of wheat barley and oat under rainfed conditions. Asian J. Plant Sci., 1, 148-150.

Tiwari, U., Cummins, E. (2009). Simulation of the factors affecting b-glucan levels during the cultivation of oats. J. Cereal Sci., 50, 175-183.

Wu, Y. W. (1983). Efefct of germination on oats and oat protein. Cereal Chem., 60, 418-420.

Zhao, G. Q., Ma, B. L., Ren, C. Z. (2009). Response of nitrogen uptake and partitioning to critical nitrogen supply in oat cultivars. Crop Sci., 49, 1040-1048.

Zhou, M. X., Glennie-Holmes, M., Robards, K., Helliwell, S. (1998). Fatty acid composition of Llipids of Australian oats. J. Cereal Sci., 28, 311-319.

Zute, S., Berga, L., Vīcupe, Z. (2011). Variability in endosperm ß-glucan content of husked and naked oat genotypes. Acta Biol. Daugavp., 11, 192-200. 